\title{
Pregnancy Outcome in Maternal Toxoplasmosis: A Case Control Study
}

\section{Pandey $\mathrm{D}^{1,2 *}$}

${ }^{1}$ Assistant Professor, Department of Obstetrics and Gynecology, Vardhman Mahavir Medical College and Safdarjung Hospital, Delhi, India

${ }^{2}$ Ex-Resident, Department of Obstetrics and Gynecology, MLN Medical College, Allahabad, UP, India

*Corresponding author: Divya Pandey, A-2, West Kidwai Nagar, Delhi-1100023, India, Email: dr_devya1@yahoo.co.in

\section{Abstract}

Objective: To evaluate seroprevalence of Toxoplasma infection in antenatal patients with Bad Obstetric History and the pregnancy outcome in the infected women.

Method: A prospective case control study was done on one hundred and seventy four women with Bad Obstetric History (cases; Group1) against one hundred and six antenatal women with normal obstetric history (controls; Group 2). Their sera sample was subjected to ELISA test for Toxoplasma IgG and IgM antibodies estimation at their first antenatal visit. All these patients were followed and their pregnancy outcome was noted.

Results: Seropositivity for Toxoplasma IgG antibodies was 43 percent, that for IgM antibodies was 25 percent and that for both IgG and IgM antibodies was 14.4 percent in Group 1. Adverse pregnancy outcome in the form of abortions were found in 50\%, preterm delivery in $4.2 \%$, Intra-uterine deaths in $9.7 \%$, congenitally malformed babies in $3.5 \%$ and neonatal death in $0.7 \%$ while $31.3 \%$ had term deliveries.

Conclusion: Seropositivity of IgG and IgM Toxoplasma antibodies was significantly higher in women with Bad Obstetric History $(\mathrm{p}<0.01)$. Toxoplasmosis occurring in ongoing pregnancy leads to adverse outcome.

Keywords: Bad obstetric history; Toxoplasma; IgG; IgM; ELISA

\section{Introduction}

Amongst other causes of Bad Obstetric History viz. genetic, hormonal and abnormal maternal immune response, maternal infections transmissible in utero at various stages of gestation are important causes of increasing perinatal morbidity and mortality [1]. Toxoplasmosis is an important cause of Bad Obstetric History leading to spontaneous abortions, stillbirth, fetal 
growth retardatation, preterm delivery or fetal demise [2].

Toxoplasmosis is a cosmopolitan disease caused by obligate intra-cellular protozoan Toxoplasma gondii. When acute infection with Toxoplasma occurs during pregnancy the parasite can infect the placenta and get transmitted to the fetus. The earlier (in gestation) the infection occurs, lesser is the incidence of transmission to the fetus but more is the severity of the infection. The outcome can be adverse in the form of abortions, intrauterine fetal death, preterm delivery, congenitally malformed baby or neonatal death. It effects are most adverse for immune compromised antenatal women and those who contract the disease during pregnancy [3].

This study was undertaken in northern part of the country to determine the seropositivity of Toxoplasmosis in antenatal women with Bad Obstetric History and its effects on pregnancy and to compare it with that in antenatal women with previous normal obstetric history attending antenatal clinic at a tertiary centre.

\section{Materials and Methods}

This study was a prospective case control study conducted on one hundred and seventy four women (Group I) with two or more abortions, still births, intrauterine deaths or neonatal deaths attending the outdoor and indoor antenatal clinics in the department of Obstetrics and Gynecology at a tertiary teaching hospital, over a period of one year. Another 106 women (Group II) without any obstetric losses were taken as control. In addition to a thorough systemic and obstetric examination, routine tests including complete urine examination, Blood group and Rh typing, VDRL test, Random blood glucose level, specific tests like USG were done in all cases.

Enzyme linked immunosorbent Assay (ELISA) was done for estimating IgM and IgG levels at their first antenatal visit and all patients were followed throughout their pregnancy to know the pregnancy outcome. The presence or absence of antibodies is defined by comparing the sample absorbance with absorbance of the cut-off control (threshold value). Samples with absorbance lower than the threshold value were considered non-reactive for Toxoplasma antibodies and these with absorbance higher than the threshold value were considered reactive for anti toxoplasma antibodies. The results were entered and analysed in Excel Sheet. The statistical analysis was also done using chi square test.

\section{Results}

Among 174 antenatal women with Bad Obstetric History (BOH) in Group 1 significant IgM titre by ELISA test for Toxoplasma was found in 25\% (44/174), IgG titre in $43 \%(75 / 174)$ and both antibodies in $14.4 \%(25 / 174)$ in study Group I in contrast to none $(0 / 106), 9.4 \%$ $(10 / 106)$ and $1.9(2 / 106)$ in control Group II respectively. This was a statistically significant $(\mathrm{p}<0.01)$ (Table 1$)$.

\begin{tabular}{|c|c|c|c|c|c|c|c|}
\hline \multirow{2}{*}{ Antibody detected } & \multicolumn{3}{|c|}{ Group I (N = 174) } & \multicolumn{3}{c|}{ Group II (N = 106) } & Tests of Significance \\
\cline { 2 - 8 } & $\mathbf{N}$ & $\mathbf{\%}$ & Total \% (N = 174) & $\mathbf{N}$ & $\mathbf{\%}$ & Total \% (N = 106) & Significance \\
\hline IgM & 44 & 31 & 25 & - & - & - & $\mathrm{P}<0.01$ \\
\hline IgG & 75 & 52 & 43 & 10 & 83 & 9.4 & $\mathrm{P}<0.01$ \\
\hline IgM \& IgG & 25 & 17 & 14.4 & 2 & 17 & 1.9 & $\mathrm{P}<0.01$ \\
\hline Total & 144 & 100 & 82.8 & 12 & 100 & 11 & \\
\hline \multicolumn{7}{|c|}{$x^{\prime}=135.65$ d.f. = 1 p $<0.01$} \\
\hline
\end{tabular}

Table 1: Antenatal women showing presence of Toxoplasma infection.

There was no significant difference in the age and parity in the two groups (Table 2). However significantly more antenatal women were urban dweller but with low literacy status (Table 2). Out of 174 women in Group 1,144 women tested positive for either or both anti
Toxoplasma (IgG and IgM) antibodies while only 12 out of 106 women in control group had only IgG antibody. Most of the women who tested positive for these antibodies were vegetarian and had no history of contact with cats (Table 2). 


\begin{tabular}{|c|c|c|c|c|}
\hline \multirow{2}{*}{\multicolumn{2}{|c|}{ Characteristics }} & Group I & Group II & \multirow{4}{*}{\begin{tabular}{|c|} 
Level of Significance \\
$p>>0.05$ NS
\end{tabular}} \\
\hline & & $(\mathrm{N}=174)$ & $(\mathrm{N}=106)$ & \\
\hline \multirow{2}{*}{ Residence } & Rural & $66(37.9 \%)$ & $42(39.6 \%)$ & \\
\hline & Urban & $108(62.1 \%)$ & $64(60.4 \%)$ & \\
\hline \multirow{2}{*}{ Education status } & Literate & $39(22.4 \%)$ & $39(36.8 \%)$ & \multirow{2}{*}{$\mathrm{P}<0.01 \mathrm{~S}$} \\
\hline & Illiterate & $135(77.6 \%)$ & $67(63.2 \%)$ & \\
\hline \multirow{2}{*}{ Food habit } & Vegetarian & $135(77.6 \%)$ & $54(51 \%)$ & \multirow{2}{*}{$\mathrm{P}<0.01 \mathrm{~S}$} \\
\hline & Non vegetarian & $39(22.4 \%)$ & $52(49 \%)$ & \\
\hline \multicolumn{2}{|c|}{ Mean age(years) } & 25 & 25.4 & $\mathrm{p}>>0.05 \mathrm{NS}$ \\
\hline \multicolumn{2}{|c|}{ Mean Parity } & 3.3 & 3.1 & $\mathrm{p}>>0.05 \mathrm{NS}$ \\
\hline \multirow{4}{*}{$\begin{array}{l}\text { History of contact with cats } \\
\text { in antenatal women with } \\
\text { toxoplasmosis }\end{array}$} & \multirow{3}{*}{ Yes } & Group I & Group II & \\
\hline & & $(\mathrm{N}=144)$ & $(\mathrm{N}=12)$ & \multirow{3}{*}{$\mathrm{p}>>0.05 \mathrm{NS}$} \\
\hline & & $23(16 \%)$ & 0 & \\
\hline & no & $121(84 \%)$ & $12(100 \%)$ & \\
\hline \multicolumn{2}{|c|}{ Significant Toxoplasma antibody titres } & Group $I(N=144)$ & Group $\mathrm{II}(\mathrm{N}=12)$ & \\
\hline \multicolumn{2}{|l|}{ IgM } & $44(25 \%)$ & $0 \%$ & $\mathrm{P}<0.01 \mathrm{~S}$ \\
\hline \multicolumn{2}{|c|}{ IgG } & $75(43 \%)$ & $10(9.4 \%)$ & $\mathrm{P}<0.01 \mathrm{~S}$ \\
\hline \multicolumn{2}{|c|}{ IgG and IgM } & $25(14.4 \%)$ & $2(1.9 \%)$ & $\mathrm{P}<0.01 \mathrm{~S}$ \\
\hline \multicolumn{2}{|c|}{ Total } & $144(82.8 \%)(144 / 174)$ & $12(11.3 \%)(12 / 106)$ & \\
\hline \multicolumn{5}{|c|}{$\mathrm{P}<0.01$ significant; NS:not significant; } \\
\hline
\end{tabular}

Table 2: Clinical profile and antibody titre comparison in two groups.

Table 3 shows the gestational age at which Toxoplasma infection was diagnosed in Group 1.Out of 75 women with IgG antibodies $33.3 \%$ were detected in first trimester and $66.7 \%$ were detected in second trimester. Out of 44 women with IgM antibodies $52.3 \%(23 / 44)$, $2.3 \%(1 / 44)$ and $9.09 \%(4 / 44)$ were detected in first, second and third trimester respectively. Out of 25 women with both IgG and IgM antibodies 80\% (20/25),4\% $(1 / 25)$ and $16 \%(4 / 25)$ were detected in first second and third trimester respectively. $17.4 \%(25 / 144)$ with IgG, $15.9 \%(23 / 144)$ with $\operatorname{IgM}$ and $13.9 \%(20 / 144)$ with $\operatorname{IgG}$ and IgM were detected in first trimester. 34.7\% (50/144) with IgG, $11.8 \%(1 / 144)$ with IgM and $0.69 \%(1 / 144)$ were detected in second trimester while $2.78 \%(4 / 144)$ with IgM and another $2.78 \%$ (4/144) with IgG and IgM were detected in last trimester.

Distribution of pregnancy outcome of study group I is shown in Table 4. Among IgM positive patients in Group I, $15.9 \%$ had abortions, $2.8 \%$ had congenitally malformed babies, $2.8 \%$ had preterm deliveries and $9.03 \%$ had intrauterine deaths. Among those with both IgG and IgM in Group II, $13.9 \%$ had abortions, $0.7 \%$ had congenitally malformed babies, $1.39 \%$ had preterm deliveries, and another $0.7 \%$ had baby who died in neonatal period. This was significantly higher than that found in control group $(\mathrm{p}<0.01)$ (Table 5).

\begin{tabular}{|c|c|c|c|c|c|c|c|c|c|}
\hline \multirow{3}{*}{ Gestational age(weeks) } & \multicolumn{9}{|c|}{ Antibody detected } \\
\hline & \multicolumn{3}{|c|}{ IgG } & \multicolumn{3}{|c|}{ IgM } & \multicolumn{3}{|r|}{ IgG\& IgM } \\
\hline & $\mathbf{n}$ & $\%$ & $\begin{array}{c}\text { Total \% } \\
(n=144)\end{array}$ & $\mathbf{n}$ & $\%$ & $\begin{array}{c}\text { Total\% } \\
(n=144)\end{array}$ & $\mathbf{n}$ & $\%$ & Total $\%(n=144)$ \\
\hline$<12-28$ & 25 & 33 & 17.4 & 23 & 52.3 & 15.9 & 20 & 80 & $13.90 \%$ \\
\hline Dec-28 & 50 & 67 & 34.7 & 1 & \#\#\# & 11.8 & 1 & 4 & $0.69 \%$ \\
\hline$>28$ & - & - & - & 4 & 9.09 & 27.8 & 4 & 16 & $2.78 \%$ \\
\hline Total & 75 & 100 & & 44 & 100 & & 25 & 100 & \\
\hline
\end{tabular}

Table 3: Gestational age of antibody detection in antenatal women with Bad Obstetric History with Toxoplasma infection in Group 1. 


\begin{tabular}{|c|c|c|c|c|c|c|c|c|c|c|c|}
\hline \multirow{3}{*}{ Pregnancy outcome } & \multicolumn{11}{|c|}{ Antibody detected } \\
\hline & \multicolumn{3}{|c|}{ IgG } & \multicolumn{3}{|r|}{ IgM } & \multicolumn{3}{|c|}{ IgG \& IgM } & \multicolumn{2}{|c|}{ Total } \\
\hline & $\mathbf{n}$ & $\%$ & $\begin{array}{c}\text { Total } \%(\mathrm{~N}= \\
144)\end{array}$ & $\mathbf{n}$ & $\%$ & $\begin{array}{c}\text { Total } \\
\%(\mathrm{~N}=144)\end{array}$ & $\mathbf{n}$ & $\%$ & \begin{tabular}{|c|} 
Total \\
$\%(\mathrm{~N}=144)$
\end{tabular} & $\mathbf{n}$ & $\%$ \\
\hline Abortions & 30 & 40 & 20.8 & 23 & 52 & 15.9 & 20 & 80 & 13.9 & 73 & 50 \\
\hline $\begin{array}{c}\text { Congenital } \\
\text { malformation }\end{array}$ & - & - & - & 4 & 9.1 & 2.8 & 1 & 4 & 0.7 & 5 & 3.5 \\
\hline Preterm delivery & - & - & - & 4 & 9.1 & 2.8 & 2 & 8 & 1.39 & 6 & 4.2 \\
\hline Macerated IUD & - & - & - & 13 & 30 & 9.03 & 1 & 4 & 0.7 & 14 & 9.7 \\
\hline Fresh IUD & - & - & - & - & - & - & - & - & - & - & - \\
\hline IUGR & - & - & - & - & - & - & - & - & - & - & - \\
\hline Neonatal death & - & - & - & - & - & - & 1 & 4 & 0.7 & 1 & 0.7 \\
\hline Term delivery & 45 & 60 & 31.3 & - & - & - & - & - & - & 4.5 & 31 \\
\hline Total & 75 & 100 & & 44 & 100 & & 25 & 100 & & 144 & 100 \\
\hline
\end{tabular}

Table 4: Pregnancy outcome in women with Toxoplasma infection in study group I $(\mathrm{N}=144)$.

\begin{tabular}{|c|c|c|c|c|c|c|c|c|c|c|c|}
\hline \multirow{3}{*}{ Pregnancy outcome } & \multicolumn{11}{|c|}{ Antibody detected } \\
\hline & \multicolumn{3}{|r|}{ IgG } & \multicolumn{3}{|r|}{ IgM } & \multicolumn{3}{|c|}{ IgG \& IgM } & \multicolumn{2}{|c|}{ Total } \\
\hline & $\mathbf{N}$ & $\%$ & Total $\%(N=12)$ & $\mathbf{n}$ & $\%$ & Total $\%(N=12)$ & $\mathbf{n}$ & $\%$ & Total $\%(N=12)$ & $\mathbf{n}$ & $\%$ \\
\hline Abortions & 2 & 20 & 16.7 & - & - & - & - & - & - & 2 & 17 \\
\hline Congenital malformation & - & - & - & - & - & - & - & - & - & - & - \\
\hline Preterm delivery & - & - & - & - & - & - & - & - & - & - & - \\
\hline Macerated IUD & - & - & - & - & - & - & - & - & - & - & - \\
\hline Fresh IUD & - & - & - & - & - & - & - & - & - & - & - \\
\hline IUGR & - & - & - & - & - & - & - & - & - & - & - \\
\hline Neonatal death & - & - & - & - & - & - & - & - & - & - & - \\
\hline Term delivery & 8 & 80 & 66.7 & - & - & - & 2 & 100 & 16.7 & 10 & 83 \\
\hline Total & & 100 & & & & & 2 & 100 & & & 100 \\
\hline
\end{tabular}

Table 4: Pregnancy outcome in women with Toxoplasma infection in control group II $(\mathrm{N}=12)$.

\begin{tabular}{|c|c|c|}
\hline S No. & Author & Seroprevalence of Toxoplasmosis \\
\hline 1 & P Yashodhara, et al. [4] & $13.10 \%$ \\
\hline 2 & D Turabadkar, et al. [1] & $10.50 \%$ \\
\hline 3 & S Chopra, et al. [5] & $42.50 \%$ \\
\hline 4 & RBSurpam, et al. [6] & $14.70 \%$ \\
\hline 5 & N Sood, et al. [7] & $18 \%$ \\
\hline 6 & Sri rupa, et al. [8] & $3.90 \%$ \\
\hline 7 & Malarvizhi, et al. [9] & $25 \%$ \\
\hline 8 & B Mistry, et al. [10] & $16.25 \%$ \\
\hline 9
\end{tabular}

Table 5: Seropositivity of Toxoplasmosis in different studies.

\section{Discussion}

In the present study it is clearly evident that Toxoplasma gondii plays a very important role in pregnancy loss. In a chronic infection by Toxoplasmosis, encysted forms of Toxoplasmosis persist in uterus and their subsequent rupture during placentation often lead to fetal infection in first trimester and abortions [12]. Among protozoal disease, a great deal is known of Toxoplasma infection. IgG denotes past infection while IgM antibodies denotes a recent infection. IgM antibodies may appear as early as 5 days after infection and reach a 
maximum within first few weeks of infection and generally declines within few weeks or months or disappear. IgG appears 1-2 weeks after the infection and reaches a maximum in 6-8 weeks and maintains a plateau for several months then declines.

In this study $67.8 \%$ were in third decade of life. This may partially reflect the age group of antenatal population in this part of the country as maximum proportion of mothers delivering at this center during the year of study also belonged to third decade of their life. In the report by Saxena, et al only $28 \%$ of women were in third decade of life [13]. Majority of the women in study had urban background and were illiterate (Table 2).Most of the women were vegetarians and did not have contact with cats (Table 2). This can be attributed to the fact that being illiterate, they were unaware of hygienic food practices of avoiding consumption of unwashed or improperly washed fruits and vegetables which could have been the source of infection.

The prevalence rate varies in different regions of world. It was approximately $90 \%$ in France and $12.41 \%$ in United States $[14,15]$. A low prevalence of $7.7 \%$ has been observed in women of childbearing age in India [16]. Among the women giving a Bad Obstetric History, the prevalence rate has been reported to be $27 \%$ [13]. A sevenfold rise in Toxoplasma Seropositivity in Chandigarh have been reported in 10 years duration from 1981-1991 [17].

In the present study IgM antibodies to Toxoplasma were found in $25 \%$ of antenatal population with Bad Obstetric History (BOH) which is in accordance to the study of B. Mistry, et al. (23.2\%) [10] and Sree Devi, et al. (16.25\%) [11] and Srirupa, et al. (18\%) [8] whereas Yashodhara P, et al. [4] , Surpam RB, et al. [6] and D. Turbadkar, et al. [1] reported Toxoplasma IgM antibodies positivity as $13.1 \%, 14.66 \%$ and $10.5 \%$ respectively. It was as low as $3.9 \%$ by Malavizhi, et al. [9] and as high as $41.3 \%$ and $42.5 \%$ by Sood N, et al. [7] and Chopra S, et al. [5] respectively (Table 5). The variation in the result was due to difference in sample size, geographical distribution, eating habits and unhygienic conditions present according to the dwellings and socio-economic status.

The incidence reported by various workers from different parts of India differs from each other (varying from 3-50\%) because of different types of tests used for screening, variable number of cases in the study and variation in prevalence in different population.
IgG antibodies were positive in $43 \%$ antenatal population with $\mathrm{BOH}$ which was similar to the result of $\mathrm{D}$. Turbadkar, et al. which was $42.1 \%$ [1] 29.8\% women with acute Toxoplasmosis had miscarriage. Apparent congenital malformations were seen in 5 cases $(3.5 \%)$ where 3 babies had hydrocephalus and 2 had neural tube defects.9.7\% pregnancies with acute infection had Intrauterine deaths and $0.7 \%$ neonatal death in contrast to $1.9 \%$ still births and neonatal death reported by Desmonts, et al. [18,19]. Sarkar, et al. have also reported the high prevalence of T.gondii in females with two followed by three abortions. And after abortions, the commonest forms of pregnancy loss due to Toxoplasmosis were stillbirths, followed by preterm deliveries, congenital anomalies and early unexplained neonatal deaths [20].

It is evident from table 3 and 4 that antenatal women in Group I with recent infection (determined by estimating $\operatorname{IgM}$ and $\operatorname{IgG}$ with $\operatorname{IgM}$ antibodies) were diagnosed in first trimester and ultimately had abortions. Thus maternal infection can lead to pregnancy wastage and its prevalence in antenatal women with Bad Obstetric History is an important risk factor. Toxoplasmosis zoonotic disease has world-wide prevalence. It occurs by ingestion of cysts of Toxoplasma from infected uncooked or undercooked meat or oocysts from soil ingested through unwashed fruits and vegetables or by transmission to fetus through transplacental transmission [10].

There is high need of teaching methods of primary prevention to our female population by following simple hygienic measures like washing fruits and vegetables thoroughly before consumption, avoiding undercooked meat, washing hands properly before eating and washing hands after handling cats or raw meat.

\section{Conclusion}

The present study demonstrates a significant seroprevalence of both IgG and IgM Toxoplasma antibodies with antenatal women with $\mathrm{BOH}$. This disease has serious consequence if acquired just before or during pregnancy in terms of adverse pregnancy and neonatal outcome. In view of high prevalence of T. gondii in our female population with repeated pregnancy wastages, it is recommended that every women of reproductive age group who has such history should be tested for her Toxoplasma serologic status prior to next conception. Those who are sero-negative should be educated regarding preventive measures. 


\section{References}

1. Turbadkar D, Mathur M, Rele M (2003) Seroprevalence of torch infection in bad obstetric history. Indian J Med Microbiol 21(2): 108-110.

2. Malik A, Rizvi M, Khan F, Rabbani T, Haris M Khan, et al. (2014) Toxoplasma gondii in women with Bad Obstetric History and infertility:a five year study. Asian Pacific Journal of Tropical Disease 4(S1): S236S239.

3. Pinard JA, Leslie NS, Irrvine PJ (2003) Maternal serologic screening for Toxoplasmosis. J Midwifery Women Health 48(5): 308-316.

4. Yashodhara P, Ramalaxmi BA, Naidu AN, Raman L (2001) Prevalence of specific IgM due to toxoplasma, rubella, CMV and c.trachomatis infections during pregnancy. Indian J Med Microbiol 19(2): 79-82.

5. Shashi Chopra, Usha Arora, Aruna Aggarwal (2004) Prevalence of IgM antibodies to Toxoplasma, Rubella and CMV infections during pregnancy. J K Sci 6(4): 190-192.

6. Surpam RB, Usha PK, Khedse RK, Qazi MS, Jalgaonkar SV (2006) Serological study for TORCH infections in women with Bad Obstetric History. J Obst Gynecol India 56(1): 41-43.

7. Sood N, Soni S, Vegad M, Gupta P (2009) Seroprevalence of Toxoplasma gondii in women with Bad Obstetric History in Ahmedabad. Gujarat Med J 64(2): 35-37.

8. Sri Rupa Pal, Das N (2006) Seroprevalence and risk factors of Toxoplasma gondii in pregnant women in Kolkata,India. J Recent Adv Appl Sci 26(1/2): 27-33.

9. Malarvizhi A, Viswanathan T, Lavanya V (2012) Seroprevalence of Toxoplasma gondii in pregnant women. J Public Health and Epidemiol 4(6): 170-177.

10. Mistry B, Salvi V, Desai SV, Dhurandhar JK, Ingle KM (1990) The role of toxoplasmosis in reproductive wastage. Journal of Obstetrics and Gynecology of India 40: 478-480.
11. Sridevi N, Nirmala Grace B, Rao BV, Kamala P (2017) Seroprevalence of Toxoplasmosis in Antenatal women with Bad Obstetric History. Int J Curr Microbiol App Sci 6(3): 732-741.

12. Langer H (1963) Repeated congenital infections with Toxoplasma gondii. Am J Obstet Gynecol 21(3): 318329.

13. Saxena K, Bano I, Aggarwal K (1993) Incidence of Toxoplasmosis in cases of bad obstetric history. J Obstet Gynaecol India 43: 703-706.

14. Mc Cabe R, Remington JS (1988) Toxoplasmosis: The Time has come. N Engl J Med 318: 313-315.

15. Sever JL, Ellenberg JH, Ley AC, Madden DL, Fuccillo DA, et al. (1988) Toxoplasmosis: Maternal and Pediatric findings in 23,000 pregnancies. Pediatrics 82(2): 181-192.

16. Mittal V, Bhatia R, Singh VK, Sehgal S (1995) Prevalence of toxoplasmosis in Indian women of childbearing age. Indian Journal of Pathology \& Microbiology 38(2): 143-145.

17. Sharma P, Gupta I, Ganguly NK, Mahajan RC, Malla N (1997) Increasing Seropositivity in India with Bad Obstetric History and in newborns. Natl Med J India 10(2): 65-66.

18. Desmonts G, Daffor F, Forestier F, Capella-Pavlovsky M, Thulliez PH, et al. (1985) Prenatal diagnosis of Congenital Toxoplasmosis. Lancet 325(8427): 500504.

19. Desmonts G, Couvreur J (1974) Congenital Toxoplasmosis A prospective study of 378 pregnancies. N Engl J Med 290(20): 1110-1116.

20. Sarkar MD, Anuradha B, Sharma N, Roy RN (2012) Seropositivity of toxoplasmosis in antenatal women with bad obstetric history in a tertiary care hospital of Andhra Pradesh, India. J Health Popul Nutr 30(1): 87-92. 